\title{
The emergence of carbapenem resistance in ESBL-producing Escherirchia coli O25B-ST131 strain from community acquired infection in Kuwait
}

\author{
AA Dashti ${ }^{*}$, L Vali ${ }^{1}$, MM Jadaon ${ }^{1}$, S El-Shazly' ${ }^{1}$ SG Amyes ${ }^{2}$ \\ From International Conference on Prevention \& Infection Control (ICPIC 2011) \\ Geneva, Switzerland. 29 June - 2 July 2011
}

\section{Introduction / objectives}

In this study we investigated a multi-drug resistant E.coli recovered from ascetic fluid of a haemodialysis patient with community-onset urinary tract infection from AlAmiri hospital in Kuwait. The patient was suffering from advanced liver disease with portal hypertension and multiple current inter abdominal abscesses.

\section{Methods}

Antimicrobial susceptibility was determined by Vitek2, Microscan, disc diffusion, E-test \& double disc method against antibiotics. PCR\& sequencing were performed forO25pabBspe,pabB, trpA, chuA, yjaA TSPE4, blaSHV, blaTEM, blaCTX-M15, bla $a_{\text {OXA-1-like, } a a c\left(6^{\prime}\right)-I b-c r, \text { tet }}$ (A), tet(B), gyrA, $\operatorname{parC}$, plasmid mediated $q n r \mathrm{~A}, q n r \mathrm{~B}$, $q n r S$, IMP, SPM, VIM, OXA-48, NDM, KPC and classes land 2 integrons.

\section{Results}

The isolate was confirmed as E. coli O25b-sequence type (ST) 131 clone of B2 phylogenetic group. The isolate was resistant to all antibiotics tested except sulfamethoxazole, trimethoprim and nitrofurantoin and Etest confirmed that it is highly resistant to meropenem, imipenem, ciprofloxacin, cefotaxime and ceftazidime with MIC values of $>16 \mathrm{mg} / \mathrm{l}, 32 \mathrm{mg} / \mathrm{l},>64 \mathrm{mg} / \mathrm{l}, 32$ $\mathrm{mg} / \mathrm{l} \&>32 \mathrm{mg} / \mathrm{l}$ respectively. PCR detected the expected sizes of the amplified resistance genes, and DNA sequencing confirmed that TEM-1, the novel SHV-122 GeneBank (GQ290211), CTX-M-15, OXA-1, variant aac
$\left(6^{\prime}\right)-I b-c r$, tet $(\mathrm{A})$ genes, VIM and KPC were present and it was found to carry a class 1 integron. No mutation was found in $g y r \mathrm{~A}$ but in $\operatorname{ParC}$ a mutation at $520 \mathrm{G}$ to C, with amino acid change $174 \mathrm{Val}$ (GTC) to Leu (CTC) was detected. QnrA, B, S and integron 2 were not present.

\section{Conclusion}

This is the first report of the emergence and the detection of a multiple antibiotic resistant E. coli O25bsequence type (ST)131 containing 2 carbapenemase genes in Kuwait.

\section{Disclosure of interest}

None declared.

\section{Author details}

${ }^{1}$ Medical Laboratory Sciences, Kuwait University, Kuwait. ${ }^{2}$ Molecular Chemotherapy, University of Edinburgh, UK.

Published: 29 June 2011

\section{doi:10.1186/1753-6561-5-S6-027}

Cite this article as: Dashti et al:: The emergence of carbapenem resistance in ESBL-producing Escherirchia coli O25B-ST131 strain from community acquired infection in Kuwait. BMC Proceedings 2011 5(Suppl 6):027.

${ }^{1}$ Medical Laboratory Sciences, Kuwait University, Kuwait

Full list of author information is available at the end of the article

C 2011 Dashti et al; licensee BioMed Central Ltd. This is an open access article distributed under the terms of the Creative Commons Attribution License (http://creativecommons.org/licenses/by/2.0), which permits unrestricted use, distribution, and reproduction in any medium, provided the original work is properly cited. 